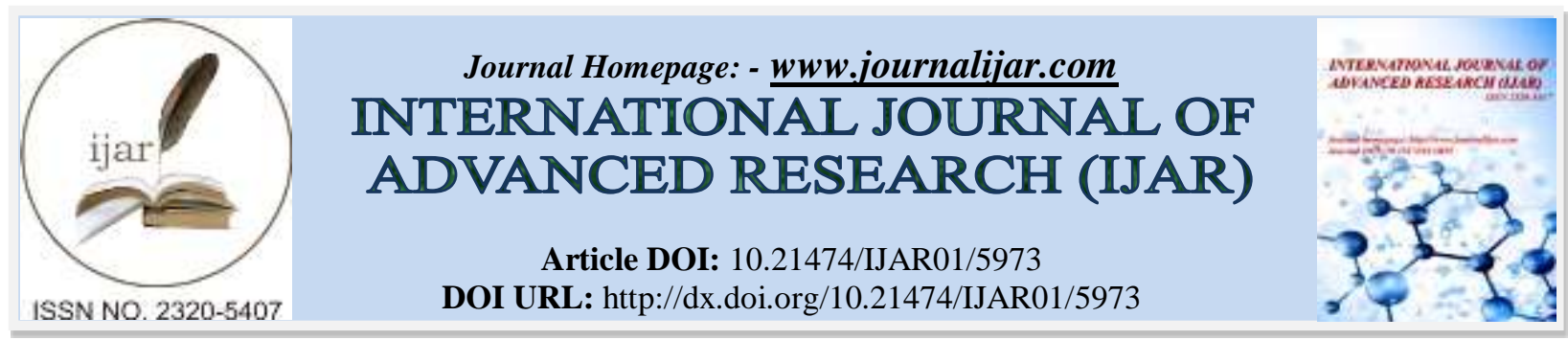

RESEARCH ARTICLE

\title{
RENEWABLE ENERGY IN INDIA: ADVANTAGES AND DISADVANTAGES OF RENEWABLE ENERGY.
}

1. Junior accounts officer, apspdcl, tirupati.

Dr. B. Madhusudhan and G. Damodhar.

2. Research scholar, dept. Of commerce, svu, tirupati.

\section{Manuscript Info}

Manuscript History

Received: 05 October 2017

Final Accepted: 07 November 2017

Published: December 2017

Key words:-

Renewabl Energy, Technologies,

Growth, Wind, Solar, Biomass, Nuclear, hydro power,

\begin{abstract}
Renewable energy describes a collection of energy technologies i.e. solar, wind, geothermal derived from sources that are never-ending and can be replenished time after time. Renewable energy is one of the environmentally friendly sources of energy and effectiveness of growth economic development of the country. India is blessed with a diversity of renewable energy sources, the main ones being Wind, Solar, Biomass, Biogas, Geothermal, Tidal and Small Hydro power. Fossil fuels are non-renewable forms of energy, meaning, they utilize limited resources that will ultimately reduce, hence, driving up overall energy costs. These very countries have responded to the threat by stepping up campaigns to embrace renewable forms of energy like solar and wind.
\end{abstract}

Copy Right, IJAR, 2017,. All rights reserved.

\section{Introduction:-}

Energy is the very important source for the economic development of any country. India, being a developing county, has witnessed a rapidly growing energy need owing to the fast industrialization and increasing demographic profile. In India growth of the economy places heavy demand of electric power, Presently Coal-based power generation is characterized by local and regional environmental degradation as well as greenhouse gas emissions, leading to climate change. Most countries across the world heavily depend on fossil fuels (oil, coal and natural gas) as sources of energy to power their economies. Fossil fuels are non-renewable forms of energy, meaning, they utilize limited resources that will ultimately reduce, hence, driving up overall energy costs. These very countries have responded to the threat by stepping up campaigns to embrace renewable forms of energy like solar and wind.

Renewable energy describes a collection of energy technologies i.e. solar, wind, geothermal derived from sources that are never-ending and can be replenished time after time. Renewable energy is one of the environmentally friendly sources of energy and effectiveness of growth economic development of the country. India is blessed with a variety of renewable energy sources, the main ones being biomass, biogas, sun, wind, geothermal, tidal and small hydro power.

\section{Energy Position in India:-}

The Indian power sector is one of the most diversified in the world. The sector has been continuously progressing in generation capacity addition through conventional like Coal, lignite, gas, hydro and nuclear power as well as nonconventional sources like Wind, solar, small hydro and biomass. The total installed capacity of $331.11 \mathrm{GW}$ with generation mix of Coal: 193,426.5 MW (58.4\%), Large Hydro: 44,765.42 MW (13.5\%), Small Hydro: 4,389.55 MW (1.3\%), Wind Power: 32,700.64 MW (9.9\%), Solar Power: 14,771.69 MW (4.5\%), Biomass: 8,295.78 MW 
(2.5\%), Nuclear: 6,780 MW (2.0\%), Gas: 25,150.38 MW (7.6\%), Diesel: 837.63 MW (0.3\%) in India as on 31 October $2017^{1}$. Renewable energy installed capacity is rapidly increased during last ten years. During the fiscal year 2016-17, the gross electricity generated by utilities in India was 1,236.39 TWH and the total electricity generation (utilities and non utilities) in the country was 1,433.4 TWH. The gross electricity consumption was 1,122 KWH per capita in the year 2016-17.

India is the world's third largest producer and fourth largest consumer of electricity. Electric energy consumption in agriculture was recorded highest (18.33\%) in 2016-17 among all countries ${ }^{1}$. The per capita electricity consumption is low compared to many countries despite cheaper electricity tariff in India ${ }^{3}$.

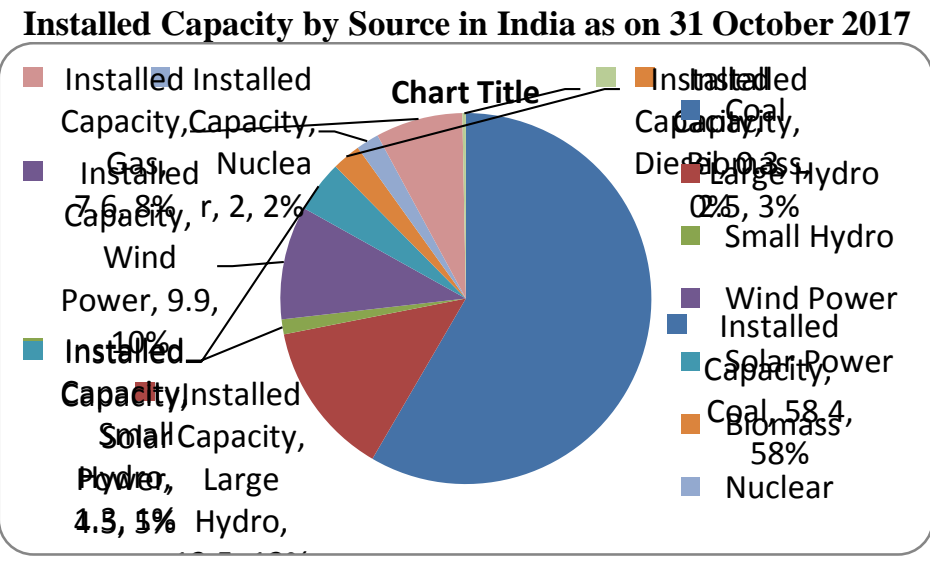

\section{Renewable Energy Overview and Targets:-}

Renewable energy sources and technologies have potential to provide solutions to the long-standing energy problems being faced by the developing countries. The renewable energy sources like wind energy, solar energy, geothermal energy, ocean energy, biomass energy and fuel cell technology can be used to overcome energy shortage in India. To meet the energy requirement for such a fast growing economy, India will require an assured supply of 34 times more energy than the total energy consumed today. The renewable energy is one of the options to meet this requirement. Today, renewable account for about $31 \%$ of India's primary energy consumptions. India is increasingly adopting responsible renewable energy techniques and taking positive steps towards carbon emissions, cleaning the air and ensuring a more sustainable future. Grid connected renewable electricity and Off-grid renewable energy installed Capacity in India as on $31^{\text {st }}$ October 2017 is given below.

Table -1:- Grid-Interactive Power (Capacities in MW)

\begin{tabular}{|l|l|l|}
\hline \multicolumn{2}{|l|}{ Installed Grid Interactive Renewable Power Capacity (excluding large hydropower) in India as of 31October } \\
\hline Source & $\begin{array}{l}\text { Total Installed } \\
\text { Capacity (MW) }\end{array}$ & 2022 target (MW) \\
\hline Wind power & 32700.64 & 60000.00 \\
\hline Solar power & 14771.69 & 100000.00 \\
\hline $\begin{array}{l}\text { Biomass power (Biomass \& } \\
\text { Gasification and Biogases Cogeneration) }\end{array}$ & 8181.7 & $* 10,000.00$ \\
\hline Waste-to-Power & 114.08 & \\
\hline Small hydropower & 4389.55 & 5000.00 \\
\hline Total & $\mathbf{6 0 1 5 7 . 6 6}$ & $\mathbf{1 7 5 0 0 0 . 0 0}$ \\
\hline
\end{tabular}

*The target is given for "Bio-power" which includes biomass power and waste to power generation. 


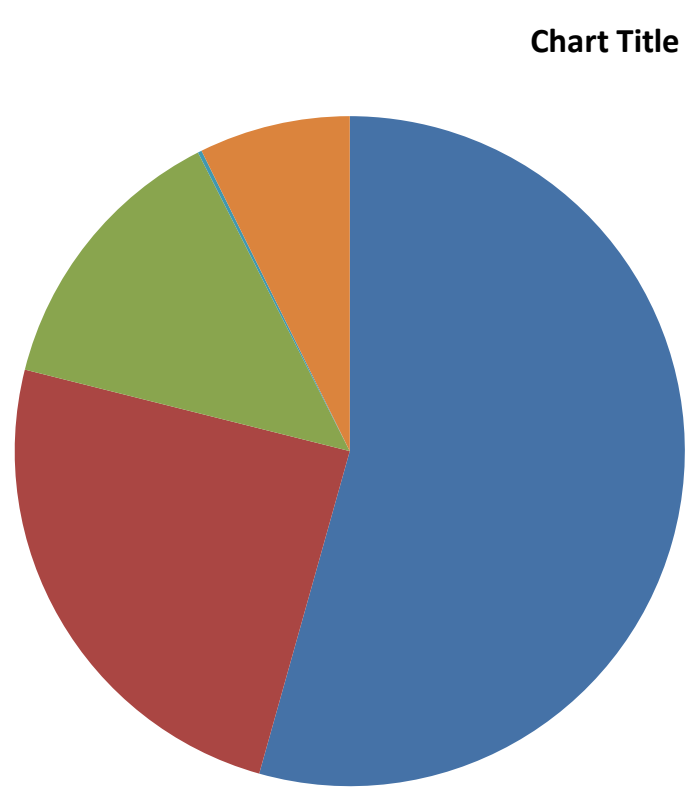

Wind power

Solar power

Biomass power

(Biomass \& Gasification and

Biogases Cogeneration)

-

Waste-to-Power

Table -2:- Off-Grid/ Captive Power (Capacities in MW)

\section{Off-Grid Power as of 31 July 2016 (MNRE) Capacities in MW}

\begin{tabular}{|l|l|}
\hline Source & Total Installed Capacity (MW) \\
\hline Biomass(Non-biogases) Cogeneration & 651.91 \\
\hline SPV Systems & 438.95 \\
\hline Biomass Gasifiers & 186.88 \\
\hline Waste to Energy & 164.45 \\
\hline Water mills / micro hydel & 18.81 \\
\hline Aero-Generators / Hybrid systems & 2.98 \\
\hline Total & $\mathbf{1 4 6 3 . 9 8}$ \\
\hline
\end{tabular}

\section{Targets:-}

The Government has up-scaled the target of renewable energy capacity to $175 \mathrm{GW}$ by the year 2022 which includes $100 \mathrm{GW}$ from solar, $60 \mathrm{GW}$ from wind, $10 \mathrm{GW}$ from bio-power and $5 \mathrm{GW}$ from small hydro-power. The target of $100 \mathrm{GW}$ capacity set under the National Solar Mission (NSM) will principally comprise of $40 \mathrm{GW}$ Rooftop and 60 GW through Large and Medium Scale Grid Connected Solar Power Projects. With this target, India will become one of the largest Green Energy producers in the world, surpassing several developed countries. Government of India in its submission to the United Nations Framework Convention on Climate Change on Intended Nationally Determined Contribution (INDC) has stated that India will achieve $40 \%$ cumulative Electric power capacity from non-fossil fuel based energy resources by 2030.

The Secretariat of International Solar Alliance is being hosted by Government of India. The Government has provided land and $\$ 30$ million (Rs.175 crore) for this secretariat, and also to support it for five years. The participants, mostly in Latin America and Africa including the US, China, and France, would work together to increase solar capacity across emerging markets. The Framework Agreement of the ISA was opened for signature on 15 November, 2016 in Marrakech, Morocco on the side-lines of 22nd Conference of Parties to the UNFCCC. So far 24 countries including India have signed the Framework Agreement. With Cabinet approval on 28 December, 2016, India has become the first country to ratify the ISA treaty.

A target of $16660 \mathrm{MW}$ grid renewable power (wind $4000 \mathrm{MW}$, solar $12000 \mathrm{MW}$, small hydro power $250 \mathrm{MW}$, biopower $400 \mathrm{MW}$ and waste to power $10 \mathrm{MW}$ ), has been set for 2016-17. Besides, under off-grid renewable system, targets of $15 \mathrm{MW}$ eq. waste to energy, $60 \mathrm{MW}$ eq. biomass non-biogases cogeneration, $10 \mathrm{MW}$ eq. biomass gasifies, 
1.0 MW eq. small wind/ hybrid systems, $100 \mathrm{MW}$ eq. solar photovoltaic systems, $1.0 \mathrm{MW}$ eq. micro hydel and 100,000 nos. family size biogas plants have been set for 2016-17.

\section{Advantages and Disadvantages of Renewable Energy :-}

There are many advantages and disadvantages to switching to renewable energy.

\section{Advantages of Renewable Energy:- \\ Renewable Energy is Good for the Environment:-}

It is a clean source of energy, meaning, it has low or zero carbon and greenhouse emission. Fossil fuels emit high levels of greenhouse gas and carbon dioxide, which are greatly responsible for global warming, climate change, and degradation of air quality. Fossil fuels also contribute to sulfur emission to the atmosphere leading to acid rains. Acid rains can cause damage to buildings. Solar and wind power are considered eco-friendly because they emit zero toxic gases to the environment. The use of renewable energy dramatically reduces the dependence on fossil fuel as a source of energy, hence, cutting back on air pollution.

\section{It's a Renewable Resource:-}

This implies that they do not deplete over a lifetime and there is zero possibility that they will run out (sustainable source of energy). Sources of energy like fossil fuels (oil, gas, and coal) are considered limited resources and there is strong possibility that they will run out in the future. Renewable energy can help developing countries from overreliance on fossil fuels. Powerful winds, heat emanating from beneath the earth, sunshine and moving water can guarantee a huge and steady energy supply to a nation for many years.

\section{Renewable Energy is a Reliable Source of Energy:-}

In the previous few decades, the use of fossil fuel has sharply increased. This over-reliance on fossil fuels has led to our security being threatened. Fossils fuels are prone to trade disputes, political instabilities, spike in energy prices and unnecessary wars. These variables affect a lot more than a nation's energy policies; they can significantly drain a county's economy.Although most argue that solar and wind energy are unreliable, a solid infrastructure puts this argument to rest. If solar and wind plants are distributed over a large geographical location, there can be minimal electricity generation interruption because weather disruptions in one location cannot be the same in other locations.

\section{Leads to Job Creation:-}

Renewable energy makes real economic sense because it is a cheaper alternative to most traditional sources of energy. Since the inception of renewable energy, new and stable jobs have been added to most world economies. For, instance, in Germany and UK, many jobs have already been created thanks to their relentless efforts to develop and encourage the use of renewable forms of energy. Experts project that with the ongoing rigorous campaigns to embrace renewable energy, thousands of stable jobs will be created.

\section{Renewable Energy has Stabilized Global Energy Prices:-}

Change up to renewable sources of energy means stability of energy prices across the globe. This is because the cost of renewable energy depends on the initial cost of installation of renewable energy technologies as opposed to fossil fuels, which increase and decrease depending on the current inflation and availability of the resource. Respective governments would only need to cater to the initial costs and that's it.

\section{Less Maintenance of Facilities:-}

Once infrastructure for the harnessing of the renewable resource is laid down, there is low to zero maintenance required. This means that the owners of the facilities will reap big profits while providing cheap electricity to the population.

\section{Empowering of People in the Countryside:-}

Renewable energy generation mainly takes place in remote settings. This means that local towns would get a fair share of power generated, ultimately, catalyzing the regeneration of those depressed areas both socially and economically. Electrification of those areas will open up untapped opportunities for development through the advancement of greenhouses using geothermal power, district heating of towns and communities through hot water generated by the energy exploitation of forestry and agricultural biomass. 


\section{Disadvantages of Renewable Energy:- \\ The Electricity Generation Capacity is still not large enough:-}

There are still challenges to generation of large quantities of power in renewable energy technology compared to traditional forms of energy generation like fossil fuel. Fossil fuel still produces large quantities of electricity today, by far. This, essentially, means that it can't be solely relied upon to power the whole nation. Energy is not a constant source of energy. This means that either we need to set up more such facilities to match up with the growing demand or look out for ways to reduce our energy consumption. This phenomenon indicates that a balance of different energy sources will still prevail for some years to come.

\section{Renewable Energy can be Unreliable:-}

Renewable energy technologies totally depend on the weather (for e.g.: sun and wind) to be able to harness any energy. In case atmospheric conditions are not good enough, renewable energy technologies would lack the ability to generate any electricity. This might instigate campaigns by the authorities to reduce energy usage in order to serve the population for a longer period.

\section{Low-Efficiency Levels:-}

Renewable energy technologies are still significantly new to the market, meaning, they still lack the much-needed efficiency. This poses forecast problems and investors may shy away from investing their money for fear of not getting returns pretty quick.

\section{Requires High Cost of Capital:-}

Setting up renewable energy generation facilities requires a huge financial outlay. Installation of wind turbine, solar panels, and hydroelectricity plants are relatively expensive. These plants require upfront investments to build, have high maintenance expenses and require careful planning and implementation. Also, the electricity generated needs to be delivered to towns and cities, which means additional cost of installing power lines. Without governmental incentives and subsidies that support the development of the green energy sector in the world, many green projects developed today would be remained only on paper. The advantages and disadvantages of renewable energy show us that this technology has great potential. We have yet to realize its full potential, however, because of certain limitations that come with renewable. With more investments into this technology, prices can be lowered, jobs can be created, and the transition toward the consumption of fewer fossil fuels can happen.

\section{Conclusion:-}

Developing economies have set ambitious Renewable Energy capacity addition targets to reduce energy exportation on estimate of their growing and developing economy. It was estimated that the emissions of greenhouse gas can be reduced from $4 \%$ to $45 \%$ in the upcoming years of 2020 . These include up to $14 \%$ by replacing coal with renewable energy.

\section{References:-}

1. https://en.wikipedia.org/wiki/Electricity_sector_in_India

2. http://mnre.gov.in/mission-and-vision-2/achievements/

3. "All India Installed Capacity of Utility Power Stations" (PDF). Retrieved 7 November 2017.

4. "Growth of Electricity Sector in India from 1947-2017"(PDF). CEA. Retrieved 17 February 2017.

5. Renewable Energy Provisions in revised tariff policy. Ministry of New and Renewable Energy. Government of India; February 2016. (Book).

6. http://en.wikipedia.org/wiki/Nuclear power in India. 